\title{
Smokey Bear and the Pyropolitics of United States Forest Governance
}

Jesse Minor and Geoffrey A. Boyce

School of Geography and Development, University of Arizona, 1064 E. Lowell St, Tucson, AZ 85721, USA

Received 5 September 2016, Revised 8 September 2017, Accepted 14 October 2017, Available online 23 October 2017

\begin{abstract}
Wildfire prevention advertisements featuring Smokey Bear represent the longeststanding and most successful government advertising and branding campaign in U.S. history. As the public face of U.S. fire control policy, Smokey Bear uses mass media to influence the attitudes and behavior of U.S. citizenry in order to accomplish particular outcomes related to wildfire prevention and suppression, forest protection, and resource management. Smokey Bear can therefore be viewed as a governmental instrument that simultaneously targets the behavior of the U.S. public and the biophysical materiality of combustible forests. Examining the evolution of Smokey Bear and related wildfire prevention media, we explore connections between state management of people, territory, and flammable landscapes. Borrowing from Nigel Clark (2011), we use the term pyropolitics to describe the resulting more-than-human assemblage of citizenship, fire suppression and forest ecology. Importantly, this pyropolitical assemblage has substantive and recursive impacts on state practice.

Through aggressive wildfire prevention and suppression that include and extend beyond Smokey Bear, the U.S. state has transformed fuel loads, species compositions, and ecosystem dynamics across North America. One result is a heightened propensity
\end{abstract}


toward catastrophic wildfire, requiring additional and sustained state intervention to maintain an imposed and unstable equilibrium. Thus even as the economic, social and cultural realities of U.S. civic life have changed over the course of the $20^{\text {th }}$ and early $21^{\text {st }}$ centuries - and even as knowledge of the ecological benefits of fire to ecosystem health has developed over time - the message of Smokey Bear has remained remarkably consistent, communicating an official imperative to prevent anthropogenic ignition.

\section{Highlights}

The U.S. state uses advertisement as a biopolitical instrument oriented toward simultaneously managing people and forests.

Smokey Bear symbolically and materially territorializes U.S. state power, linking citizenship, fire practices, and ecology.

Smokey's message is flexible in the face of social, economic and environmental change.

Ecological consequences of fire prevention create an environmental feedback loop requiring ongoing U.S. state intervention.

Keywords: advertising; biopolitics; environmentality; governmentality; posthumanism; state theory; wildfire

\section{Introduction}

In North America the prevention, suppression, and management of wildfire has played a critical role in historical processes of colonial dispossession and the institutional development, ideological expression and material composition of state power. Beginning in the $19^{\text {th }}$ century a singular rationale came to rule this fire management regime: total fire suppression. Until the 1970s the official attitude was that wildland fire had no inherent ecological benefit and was a destructive force requiring militaristic intervention to suppress and eliminate from the American landscape (Pyne 2001: 253254). 
The invention of Smokey Bear in 1944 created a unique platform for the U.S. state to channel its fire suppression agenda through influencing the conduct of its citizenry. Smokey Bear symbolizes a pivot point at which nationwide fire prevention and suppression policies were materialized and communicated through an enormously successful advertising campaign that continues to the present. In the process, Smokey Bear has become the longest-running public advertising campaign in U.S. history, while serving as an avatar, symbol and instrument of fire prevention on U.S. public lands.

In this paper we examine the evolution of Smokey Bear and related wildfire prevention media, exploring connections between state management of people, territory, and flammable landscapes. In the process, we contribute to broader conversations in political geography that attend to the complex more-than-human articulation of state power with the material objects and multiplicities in and through which it acts (Braun \& Whatmore, 2010; Sundberg, 2011; Dittmer, 2013; Peloquin, 2013; Shaw \& Meehan, 2013; Squire, 2015). Meehan, Shaw, \& Marston (2013), for example, unpack the ways that non-human objects translate, mediate, and complicate state surveillance and policing, oftentimes producing or contributing to outcomes wholly unanticipated by their protagonists. More recently Boyce (2016) and Clark \& Jones (2016) have expanded on this work to explore the ways that non-human multiplicities complicate the territorial composition of state power and its geopolitical expression. In this paper we pursue a dialogue between the literature above and work that is concerned expressly with the emergence of a "state effect" through the prosaic cultivation of desired behaviors and practices of citizenship among a media-consuming public (Painter, 2006; Mitchell, 1999; Rose, 1999). Governance, in this sense, most closely follows Foucault's definition laid out in Security, Territory, Population, which is expressed as "the development of a series of specific governmental apparatuses on the one hand, [and, on the other] to the development of a series of knowledges" (Foucault 2007: 108-109). This process occurs not merely at the level of institutions or the discourses these circulate, but through the disciplining and rationalization of subjects into selfregulation in service of state goals - a process that Foucault captures through his concept of governmentality. According to Garmany (2010), governmentality is a 
powerful concept for examining the technical expression of state conduct because its logic is intimately associated with internally consistent categories like 'truth' and 'knowledge.' Government advertising and propaganda, then, is a useful lens for examining the production and dissemination of official 'truths,' intended for consumption by a broad public who would thereby internalize particular attitudes and express certain behaviors desired by state actors and agencies. Yet in the case of Smokey Bear, and U.S. wildfire prevention advertising more broadly, the target of government intervention is not individual attitudes and behavior. Rather, these are instrumentalized in order to accomplish a broader set of environmental outcomes related to the United States' expansive forestlands (and fire-prone wildlands, woodlands and grasslands), including their availability for extractive accumulation. It is through what we call (borrowing from Nigel Clark [2011]) the "pyropolitics" of fire control that, we contend, citizenship and state power have become entangled with the ecology and composition of forestlands across vast expanses of North America. At the same time, the resulting accumulation of fuel loads and dramatic intensification of fire size and severity have come to put considerable strain on management agencies. The result is a feedback loop in which the physiological transformation of the forest requires further and continuous state intervention to maintain an unstable equilibrium and prevent catastrophic loss. Indeed, forest management agencies have recently seen so much of their budgets devoted to fire suppression and other fire-related tasks that this arguably demonstrates a novel form of agency capture (following Clarke \& McCool, 1996) by a demanding constituency: wildfire and its apparatuses.

A considerable literature already exists examining the environmental feedbacks involved in wildfire management and suppression (Pyne, 1982; 1997; 1998; 2001; Dods, 2002; Donovan \& Brown, 2007; Collins, 2008; Marlon et al., 2012). Of interest to us here is the degree to which, even as the consequences of total fire suppression have come to be understood, and as U.S. policy has moved haltingly - if decisively - away from this management paradigm, the Smokey Bear campaign continues to penetrate the U.S. media environment with a message about forests and fire use that remains virtually unaltered: framing fire as a perpetual, exogenous and existential threat to U.S. 
forests and wildlands, but one that is endemic to the citizenry - and asserting that it is therefore the individual responsibility of every citizen to prevent uncontrolled ignition. On the one hand, the continuity of Smokey Bear's message is understandable. The U.S. wildfire prevention advertising campaign helped to birth a dramatic transformation of forest dynamics, while the suppression of routine burning combined with demographic shifts in the country to dramatically alter residential settlement patterns, increasing the vulnerability of critical infrastructure and millions of homes and persons to wildland fire (Radeloff et al., 2005; Gill \& Stephens, 2009; Stein et al., 2013; Simon, 2014; 2016). For this reason, a genealogical examination of the Smokey Bear campaign reveals the temporal dimension of those more-than-human assemblages that drive, compose and condition state power. In the case of wildfire prevention this process exhibits a kind of path dependency, wherein state decisions and initiatives significantly impact material conditions and the resources and strategies required to manage these many years down the road. Unpacking the temporal dis/continuities of the Smokey Bear campaign reveals how non-human objects and ecosystem dynamics may articulate with state practice not just by driving unexpected outcomes that "disrupt," "resist" or "unravel” the ambitions and interventions of state actors (Clark \& Jones, 2016; Boyce, 2016; Meehan, Shaw \& Marston, 2013), but also by generating outcomes and conditions that demand ongoing state intervention - at least if catastrophic loss is to be avoided.

To expand on this argument, we first discuss the methodology we bring to bear on the U.S. Forest Service's wildfire prevention advertising archive. We then review the historical background of fire exclusion in North America, in order to contextualize $20^{\text {th }}$ century and contemporary wildfire prevention efforts. We provide an abbreviated description and genealogy of the wildfire prevention campaign, with special focus on the role of Smokey Bear as a powerful and longstanding discursive motif, component of, and shorthand for the state's wildfire prevention advertising effort. Unpacking a series of Smokey-related images that track the bear's nearly 80-year sojourn, we explore how Smokey has responded to tremendous changes to the cultural and media landscapes of the United States, while simultaneously mobilizing various symbolic 
motifs to naturalize contemporary management practices and cultivate "proper" attitudes about fire and forest use. We then consider the accumulated impacts of these attitudes and management practices to explain Smokey's continued relevance as an instrument and medium of governance. In the process, we return to the problems of "governmentality" and its corresponding "state effect," including the temporal, as well as spatial, implications of their more-than-human articulation. We conclude by suggesting several areas for future inquiry, including how a pyropolitical research agenda might develop and expand upon the complex articulations of citizenship, fire use and state practice considered below.

\section{A Note on Methodology}

In the text that follows we draw on fire science and environmental history to support and contextualize our claims related to Smokey Bear's unique contributions to the project of fire prevention and control on U.S. public lands. It is not our assertion that Smokey alone explains any specific set of environmental outcomes. Rather, Smokey serves as just one piece of a larger fire control apparatus, whose scientific understanding of forest ecology and the policy prescriptions that follow have been contested and adapted over time. We focus on Smokey as an object of analysis because we believe that this campaign provides a powerful and compelling entrée into the

"fiery entanglement" (Edwards \& Gill, 2016) of forest governance, citizenship and the territorialization of state power in North America. We are therefore interested in tracing the genealogy of the Smokey campaign, and we understand Smokey himself (through his various incarnations and media appearances) as a non-human actor in the specific Latourian sense of "[modifying] a state of affairs by making a difference" (Latour, 2005: 71).

Toward this end, we employ a critical visual methodology that examines visual objects, including static images and video, in relation to the social conditions of their production and their material effects (Rose, 2001: 15). This is pursued using a discourse analysis that simultaneously examines image and text, the power relations involved in the production and consumption of imagery, and the social and 
environmental outcomes that can be attributed to these advertisements (at least, according to official accounts). Our primary data are wildfire prevention advertisements produced from 1939 to 2014, which span a suite of formats ranging from printed posters, billboards, radio and TV spots, to contemporary online digital advertisements. Most of these items are publicly available through archives housed in the Library of Congress, the USDA's National Agricultural Library, and the website SmokeyBear.com, which is jointly maintained by the Forest Service and the Ad Council. Several items are drawn from the private collection of Tom Swetnam, a tree-ring researcher at the University of Arizona. Citations for these items are compiled in Table 1.

Table 1: Citations and locations of figures and videos referred to in the text.

\begin{tabular}{|c|c|}
\hline $\begin{array}{l}\text { Figure \# or } \\
\text { Video Name }\end{array}$ & Citation \\
\hline 1 & $\begin{array}{l}\text { Staehle, Albert (artist). 1944. Source: “Another enemy to conquer. } \\
\text { Forest Fires. } 9 \text { out of } 10 \text { can be prevented." Special Collections, USDA } \\
\text { National Agricultural Library. Accessed March 24, 2016, } \\
\text { https://www.nal.usda.gov/exhibits/speccoll/items/show/456. }\end{array}$ \\
\hline $2 \mathrm{~A}$ & $\begin{array}{l}\text { Poster 516145; Records of the Office of Government Reports, Record } \\
\text { Group 44; National Archives at College Park, College Park, MD. }\end{array}$ \\
\hline 2B & $\begin{array}{l}\text { Poster 514135; Records of the Office of Government Reports, Record } \\
\text { Group 44; National Archives at College Park, College Park, MD. }\end{array}$ \\
\hline 3 & $\begin{array}{l}\text { Hirshman, Louis (artist). 1941-1943. Source: Library of Congress Prints } \\
\text { and Photographs Division Washington, D.C. } 20540 \text { USA. Call Number: } \\
\text { POS - WPA - PA .H57, no. 2. URL: } \\
\text { http://hdl.loc.gov/loc.pnp/cph.3b49005. }\end{array}$ \\
\hline 4 & $\begin{array}{l}\text { SmokeyBear.com. 2016. Accessed March 24, 2016, } \\
\text { https://smokeybear.com/en/smokeys- } \\
\text { history?decade=1940\&item=f0b02e30. }\end{array}$ \\
\hline
\end{tabular}




\begin{tabular}{|c|c|}
\hline $5 \mathrm{~A}$ & $\begin{array}{l}\text { Special Collections, USDA National Agricultural Library. URL: } \\
\text { https://specialcollections.nal.usda.gov/guide-collections/us-forest- } \\
\text { service-smokey-bear-collection/only-you-can-prevent-wildfires. }\end{array}$ \\
\hline 5B & $\begin{array}{l}\text { Special Collections, USDA National Agricultural Library. URL: } \\
\text { https://specialcollections.nal.usda.gov/guide-collections/us-forest- } \\
\text { service-smokey-bear-collection/only-you-can-prevent-wildfires. }\end{array}$ \\
\hline 6 & $\begin{array}{l}\text { SmokeyBear.com. 1954. Accessed March 24, 2016, } \\
\text { https://smokeybear.com/en/smokeys-history?decade=1950 }\end{array}$ \\
\hline $7 \mathrm{~A}$ & $\begin{array}{l}\text { SmokeyBear.com. 1956. Accessed March 24, 2016, } \\
\text { https://smokeybear.com/en/smokeys-history?decade=1950 }\end{array}$ \\
\hline 7B & $\begin{array}{l}\text { SmokeyBear.com. 1956. Accessed March 24, 2016, } \\
\text { https://smokeybear.com/en/smokeys-history?decade=1950 }\end{array}$ \\
\hline 8A & $\begin{array}{l}\text { SmokeyBear.com. 1976. Accessed August 31, 2016, } \\
\text { https://smokeybear.com/en/smokeys- } \\
\text { history?decade=1970\&item=e5df2e42 }\end{array}$ \\
\hline 8B & $\begin{array}{l}\text { SmokeyBear.com. 1975. “Great Americans.” Accessed August 31, 2016, } \\
\text { https://smokeybear.com/en/smokeys- } \\
\text { history?decade=1970\&item=cNRz-rsztWY }\end{array}$ \\
\hline $9 \mathrm{~A}$ & $\begin{array}{l}\text { Martin, B.E. 1943. "Plow around for safety." Special Collections, USDA } \\
\text { National Agricultural Library. Accessed March 24, 2016, } \\
\text { https://www.nal.usda.gov/exhibits/speccoll/items/show/8221. }\end{array}$ \\
\hline $9 \mathrm{~B}$ & 1981. Private collection of Dr. Tom Swetnam, Tucson, Arizona. \\
\hline $10 \mathrm{~A}$ & $\begin{array}{l}\text { SmokeyBear.com. 1959. Accessed August 31, 2016, } \\
\text { https://smokeybear.com/en/smokeys- } \\
\text { history?decade=1950\&item=9c487d42 }\end{array}$ \\
\hline $10 \mathrm{~B}$ & $\begin{array}{l}\text { SmokeyBear.com. 1953. Accessed August 31, 2016, } \\
\text { https://smokeybear.com/en/smokeys-history?decade=1950 }\end{array}$ \\
\hline 11 & 1983. Private collection of Dr. Tom Swetnam, Tucson, Arizona. \\
\hline
\end{tabular}




\begin{tabular}{|c|c|}
\hline 12 & $\begin{array}{l}\text { Unknown. 1974. “Matchbook." Smokeybear.com. Accessed March 24, } \\
\text { 2016, } \\
\text { http://www.smokeybear.com/vault/\#!prettyPhoto[1970sT]/13/ }\end{array}$ \\
\hline 13 & $\begin{array}{l}\text { Unknown. 1978. "Remember there are babes in the woods." Special } \\
\text { Collections, USDA National Agricultural Library. Accessed March 24, } \\
\text { 2016, https://www.nal.usda.gov/exhibits/speccoll/items/show/449. }\end{array}$ \\
\hline 14 & $\begin{array}{l}\text { Wendelin, Rudy. 1994. “Trees are Wonderful Friends.” Special } \\
\text { Collections, USDA National Agricultural Library. Accessed March 22, } \\
\text { 2016, https://www.nal.usda.gov/exhibits/speccoll/items/show/421. }\end{array}$ \\
\hline $15 \mathrm{~A}$ & $\begin{array}{l}\text { Unknown. 1977. “Repeat after me, 'Only you...'." Special Collections, } \\
\text { USDA National Agricultural Library. Accessed March 24, 2016, } \\
\text { https://www.nal.usda.gov/exhibits/speccoll/items/show/458. }\end{array}$ \\
\hline 15B & $\begin{array}{l}\text { Unknown. 1989. “Only You.” Special Collections, USDA National } \\
\text { Agricultural Library. Accessed March 24, 2016, } \\
\text { https://www.nal.usda.gov/exhibits/speccoll/items/show/459. }\end{array}$ \\
\hline 16 & $\begin{array}{l}\text { Wendelin, Rudy. 1988. "Nature's Gold Medal Winner.” Special } \\
\text { Collections, USDA National Agricultural Library. Accessed March 22, } \\
\text { 2016, https://www.nal.usda.gov/exhibits/speccoll/items/show/415. }\end{array}$ \\
\hline 17 & 1948. Private collection of Dr. Tom Swetnam, Tucson, Arizona \\
\hline $\begin{array}{l}\text { "Bomb in } \\
\text { the Forest" }\end{array}$ & $\begin{array}{l}\text { SmokeyBear.com. "Bomb in the Forest." 1969. Accessed March 24, } \\
\text { 2016, http://www.smokeybear.com/vault/\#!prettyPhoto[1960sT]/3/. }\end{array}$ \\
\hline $\begin{array}{l}\text { “Do Trees } \\
\text { Think” }\end{array}$ & $\begin{array}{l}\text { SmokeyBear.com. “Do Trees Think?” 1989. Accessed March 24, 2016, } \\
\text { http://www.smokeybear.com/vault/\#!prettyPhoto[1980sT]/10/. }\end{array}$ \\
\hline "Neighbors" & $\begin{array}{l}\text { SmokeyBear.com. “Neighbors.” 2011. Accessed August 31, 2016, } \\
\text { https://smokeybear.com/en/smokeys- } \\
\text { history?decade=2010\&item=YZ6sE01cR30. }\end{array}$ \\
\hline
\end{tabular}

We analyze the text and image content of wildfire prevention advertisements spanning decades to identify their central message, as well as for visual or textual elements that illustrate symbolic or discursive connections to non-wildfire elements such as 
economic, cultural, social, ecological, or other themes. In particular, we are interested in the ways that the advertisements transform to reflect the evolution of national identity and culture over the course of the $20^{\text {th }}$ century, all while affirming the state's authority as arbiter and manager of U.S. public lands and reinforcing a consistent message related to the control of ignition as an individual moral imperative. This message of fire prevention continues in 2017 even as U.S. fire management policy and the demographics of forest residents and users changed considerably over the past 70+ years. We therefore believe that the temporal depth of these advertisements allows an examination of the becoming together of forest ecology, citizenship and land management, which recursively interact in complex ways to symbolically and materially territorialize state power in North America. But before delving into state- sponsored wildfire prevention media, it is useful to situate Smokey Bear and contemporary U.S. fire and forest management policy within a much longer genealogy of aggressive Euro-American fire exclusion in what is today the United States.

\section{Fire Suppression and the Territorialization of the United States}

Fire use is one of the defining characteristics of being human, its manipulation giving our species a pronounced advantage in the metabolic processing of energy from our environment. The use and manipulation of fire entangles our lives in complex ways with the material conditions that sustain us, decisively and continuously altering the latter. From aboriginal Australia, to the vast forest lands of the Americas, to contemporary swidden agriculture practices the world over, fire is used as a means to accelerate the circulation of nutrients and energy within an ecosystem, and to produce a variety of boundary and successional ecosystems that attract and promote the proliferation of desirable species.

As elaborated by Pyne $(1997 ; 2001)$, a great exception to this pattern of landscape management was early-modern Europe, where fire was associated with the propensity of peasant classes toward waste, mismanagement, and rebellion - leading to fire suppression as a mechanism and justification for enclosure (Pyne, 1997; 2001). First, the Foresta Regis was established as a preserve for game and timber production that 
could be channeled to the state's increasingly urgent needs for resource production to support urban construction and shipbuilding. Fire suppression was then extended to communally-held lands as a means to rationalize and scientifically manage agricultural production (indeed, as Marder [2015] suggests, the project of enlightenment itself might be read as an effort to separate the process of illumination from the danger, heat and unruliness of combustion). Observes Clark (2011: 177):

"For the new metropolitan intelligentsia and officialdom, fire was experienced primarily as an expression of social unrest or breakdown, a mark of excess and disorder. It is no coincidence that the notion of curfew, as a means of keeping tabs on the populace, is derived from couvre feu, covering or dousing a fire.... Just as unruly urbanites were being induced to channel and augment their bodily energies, Europe's peasant farmers were compelled to quell their fires and desist from fallow - so as to tighten and amplify the energetic circuits of agricultural production"

On the other hand, as European settlement accelerated in eastern North America, longstanding traditions of indigenous burning influenced Euro-American fire use to such a degree that colonial-era fire prevention statutes were slow to take hold, and social and economic practices centered on broadcast burning persisted until well into the $20^{\text {th }}$ century (particularly in the U.S. South. See Pyne, 1982: 146-148; 164). But as the U.S. army and settler vigilantes 'pacified' those North American territories annexed and colonized over the course of the $19^{\text {th }}$ century, Prussian models of forestry made their way across the Atlantic, inaugurating a new era of 'scientific' forest management based on the maximization of timber yields. But before forest growth could be rationalized, fire and fire use would have to be brought to heel. F.E. Olmsted perhaps best summarized this imperative, stating in 1911:

"It is said that we should follow the savage's example of 'burning up the woods' to a small extent in order that they may not be burnt up to a greater extent bye and bye. This is not forestry; not conservation; it is simple destruction... the Government, first of all, must keep its lands producing timber crops indefinitely, and it is wholly impossible to do this without protecting, encouraging, and bringing to maturity every bit of natural young growth... Fires and young trees cannot exist together. We must, therefore, attempt to keep fire out absolutely." (in Carle, 2002: 20) 
These attitudes were increasingly incorporated into law beginning with emergencyspending powers (35 Stat. 251) passed in 1908 that granted the U.S. Forest Service the flexibility to redirect any funds within its budget toward fighting wildfire, to be subsequently reimbursed by the U.S. Congress (Busenberg, 2004). In 1905 the Forest Transfer Act significantly expanded the size of U.S. forest reserves, and placed jurisdiction of National Forest lands under the U.S. Department of Agriculture. The powers of the Forest Service were expanded still further in 1911 with the Weeks Act, which allowed the Forest Service to provide matching funds to enlist state and local government agencies in joint fire suppression efforts, with then-chief forester of the United States Henry Graves declaring the prevention of forest fire to be "the fundamental obligation of the Forest Service [which] takes precedence over all other duties" (quoted in Kosek, 2006: 190). Finally, with the 1924 Clarke-McNary Act the federal government's development toward a paradigm of total fire suppression expanded to "all forest-producing lands" in the United States. These expansive forest holdings, underpinned by new laws and coupled to a nationwide fire suppression policy, set the stage for U.S. government agencies to begin aggressively enlisting the "public" as an instrument of this emergent political ecology. But it would take several decades and a wartime mobilization for the eventual strategy to materialize.

\section{World War and the Advent of Smokey Bear}

Developing in scale and complexity throughout the early years of the $20^{\text {th }}$ century, fire suppression techniques in the United States had by the 1940s come to emulate military exercises, employing smoke jumpers, bulldozers, and a formal incident command structure. But the militarization of fire suppression reached its zenith with the outbreak of the Second World War. As discussed by Kosek (2006), wildfire becamecast as a critical front in the domestic war effort - with fire framed as a threat to public order and safety; a costly diversion of labor away from wartime production; and a destruction of vital natural resources needed for construction, shipbuilding, and energy production. 
During the early years of the war a small number of wildfire prevention posters were produced by the Federal Art Project, a Depression-era program of the Works Progress Administration (WPA) that employed thousands of artists to produce public murals, sculptures, and posters. The artist Albert Staehle, who was later commissioned to draw the first versions of Smokey Bear, produced a late WPA-era poster that positions forest fire as an enemy of the state (Figure 1). In effect, these WPA posters reflected an attempt to enroll the American public into a wartime domestic front that also included resource conservation (scrap drives, water saving, victory gardens, and so forth) and civil defense. As the war progressed the Forest Service's advertising effort became a greater priority, with the agency recruiting the Wartime Advertising Council and private companies such as FCB West to provide expertise, design support, and strategy for the first ever coordinated nationwide fire prevention media campaign. The approach they developed depicts the military and geopolitical goals of the Axis as being advanced by any combustion on U.S. forestlands. Fire-focused posters demonstrate a concern with resource destruction and with the provisioning of war supplies as a rationale for conservation. In this sense, the logics of forest protection are entirely aligned with a distant war effort, which became so all-encompassing that wildfire prevention propaganda began to combine messages about labor and economic production (Figure 2) with overtly racist depictions of foreign soldiers (Figure 3). 


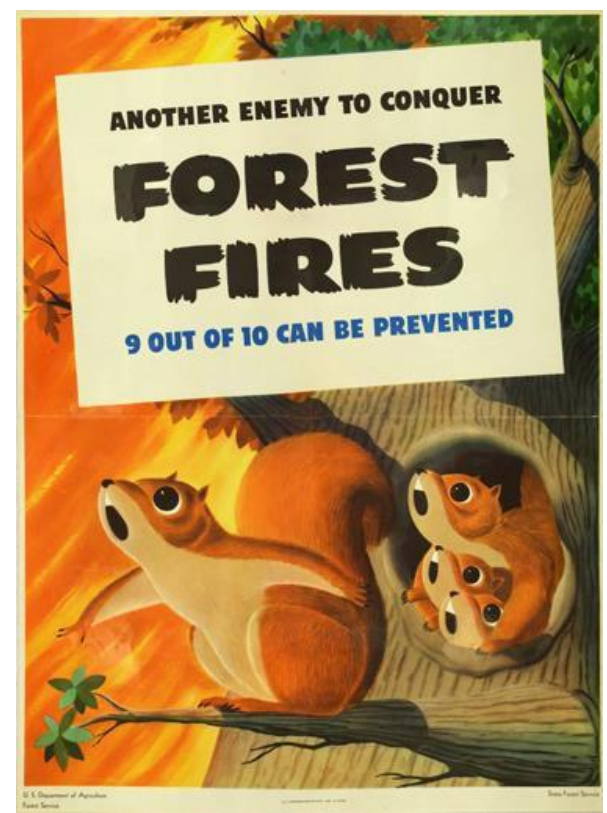

Figure 1: During WWII, forest fire was reimagined as a domestic front for the American public. Images such as this 1944 poster by Albert Staehle, the creator of Smokey Bear, served to align the forest-using public with state objectives that extended into foreign war theaters.


Figure 2: Wartime resource production, including timber for shipbuilding and food for soldiers and citizens alike, was discursively and rhetorically connected to domestic wildfire prevention campaigns. Resource shortages (including labor) were tied to the threat of wildfire, including combustion products such as smoke. 


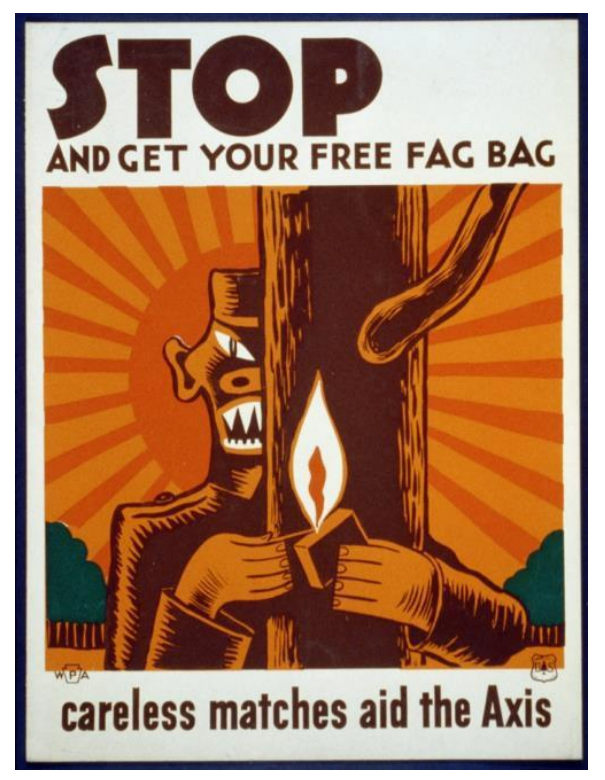

Figure 3: Racist imagery was used to stoke fears of Japanese incendiarism and domestic sabotage of forest resources. Wildfire was envisioned as an exogenous threat to forests, simultaneously at risk from foreign aggressors and careless domestic sympathizers of U.S. enemies.

Yet crucially, although forest fire is conflated with the existential menace of the nation's overseas enemies, the message of the advertisements reveals that it is the conduct of the citizenry that generates the threat, and this must therefore be monitored, modified and controlled to prevent unwanted ignition. Fire, viewed through this lens, is a ubiquitous, exogenous danger, whose cause is not foreign sabotage or infiltration - but carelessness on the part of a fire-using public. Observes Kosek (2006):

"Carelessness becomes an internal weapon in aid of the enemy, one that requires the proper internal regulation of the self. Policing moves from the protection of borders of the territory to the regulating of populations within the territory to the regulating of one's own potentially deviant behavior and carelessness. It is the message of carelessness and social deviance that becomes the central tenet of the next stage of the advertising campaign." (Kosek, 2006: 200)

This message is exemplified in Figure 2. While the two posters draw a firm parallel between military success and the labor performed in primary economic production in 
the form of timber cutting and agriculture, each also includes a small inset featuring Adolph Hitler and a skeletal, bucktoothed Hideki Tojo, cautioning against careless fire use.

As the war progressed, the Wartime Advertising Council and Forest Service identified a need to consolidate the state's wildfire prevention message through the voice of a single messenger - one who would carry the patriotic bravado required by the war, but who could also maintain continuity of message in peace time. Enter Smokey Bear - a kid-friendly forest mascot who would incorporate multiple state narratives and objectives into a benign spokesbear for the national wildfire prevention campaign. On August 9, 1944 Smokey debuted in a poster declaring "Smokey says: Care will prevent 9 out of 10 woods fires!" (Figure 4).

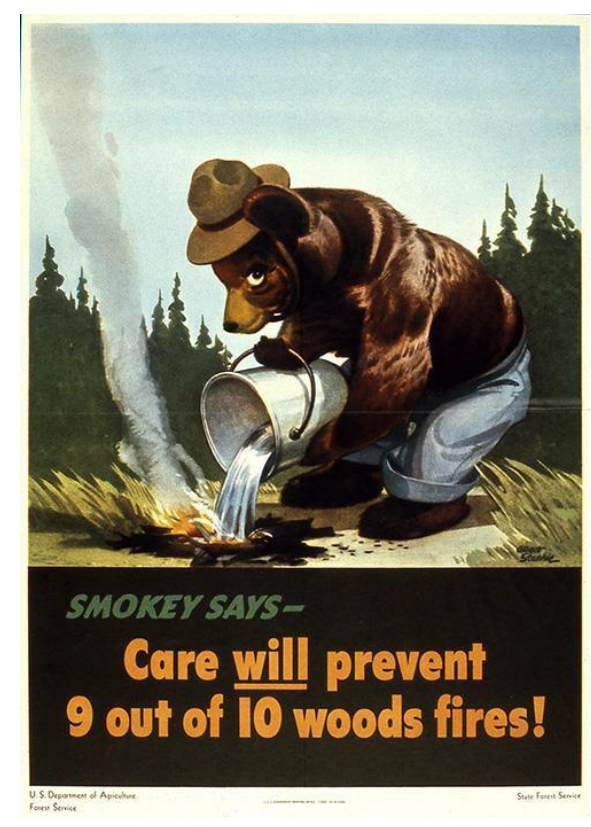

Figure 4: The first ad depicting Smokey Bear (1944) contained language that sought to manage fire use and limit forest fire ignitions through influencing fire behavior of the U.S. public.

\section{Smokey Bear: Biography of a National Icon}

Since 1944 Smokey Bear has remained a visible national icon, penetrating the U.S. media landscape and interpellating the U.S. public into "proper" forest conduct using the iconic slogan (first introduced in 1947) that would eventually become synonymous 
with the bear himself: "REMEMBER: Only YOU Can Prevent Forest Fires." In the process, Smokey has become the longest-running and most expensive government propaganda campaign in U.S. history. After the war, the Wartime Advertising Council truncated its name to the Advertising (Ad) Council and as of 2017 it continues to manage Smokey Bear's official image, having since expanded to a website and social media accounts across Facebook, Twitter, You Tube, and MySpace (see Cooperative Forest Fire Prevention Program [CFFPP], 2011). The site of production of Smokey Bear and his image results from a peculiar epistemic space in which a national wildfire control apparatus intersects with the advertising industry. This public-private nexus has proven to be enormously successful at producing state-sanctioned media, and mutualisms between the needs of the public face of the advertising industry and the biopolitical incentives of the U.S. fire management apparatus have been effective at reshaping the U.S. public's opinions, attitudes, and behavior towards fire.

As one of the most recognizable faces of government and as an exemplar of state wildfire prevention propaganda, Smokey Bear enjoys unique legal protections and inhabits a special place in formalized governance. In fact, the U.S. government's protection of Smokey Bear is interpreted to supersede traditional applications of fair use of copyrighted materials, which is generally allowed for "transformative" purposes, including critique, commentary, and parody. According to a statement on the USDA National Agricultural Library's Special Collections webpage, "The use of Smokey Bear images requires the approval of the U.S. Forest Service and must be associated with a message of fire prevention." The website then supplies contact information for the National Fire Prevention Coordinator's office.

This extraordinary investment in the protection of Smokey Bear's image, use, and copyright was first enacted by legislation in 1952 under PL 82-359, which removed Smokey Bear from the public domain and assigned rights to the bear and his image to the U.S. Secretary of Agriculture (CFFPP, 2011). Commercial interest in Smokey continued to rise, and in 1974's PL 93-318 the first "Smokey Bear Act" was amended to allow commercial licensing, with the caveat that royalties and licensing fees be used to extend the message of fire prevention (CFFPP, 2011). A series of additional regulations 
address the physical manifestation and public presentation of Smokey Bear in the form of costumes. These regulations include a list of approved manufacturers of the costumes themselves, and a number of mandates and prohibitions (e.g., never appearing in less than full costume; no speaking while in costume; a requirement that the costumed bear be escorted by a uniformed escort at all times). The above effort to control Smokey's image and prevent unauthorized usage is illustrative of Smokey's special status as a proxy for state power, and an associated determination to maintain purity of message whenever Smokey Bear is encountered by the public.

Due to his profile and attractiveness to children, Smokey Bear received and continues to receive a tremendous amount of mail. The volume has been so great that in 1965, the government granted Smokey Bear his own zip code by the U.S. Postal Service (CFFPP, 2011; Figure 5); the only other celebrity granted a personalized Postal Service zip code is the U.S. President. The U.S. Forest Service, in association with its partners in the advertising industry and with the National Zoo in Washington, DC, also made a considerable attempt to rectify the well-publicized image of their cartoon spokes-bear with a 'real' physical embodiment of Smokey Bear. In 1950, a black bear cub was rescued from a wildfire burning in the Capitan Mountains of New Mexico. The bear was quickly approved for residency at the National Zoo and promoted as the 'real' Smokey Bear. The temporal disjunction between the notional Smokey, who was real enough in terms of discourse and content production, and the biological Smokey, has been

repeatedly elided by "official" histories of Smokey Bear. For example, in "The True Story of Smokey Bear," a publication distributed in 1960 by the Forest Service and the Ad Council, Smokey's "origin story" in New Mexico's Capitan Fire is illustrated bearing no mention of the ad campaign that predated its physical avatar (Ad Council, 1960). This kind of temporal slippage is reflective of the broader iconography of the Smokey campaign, an issue to which we now turn. 

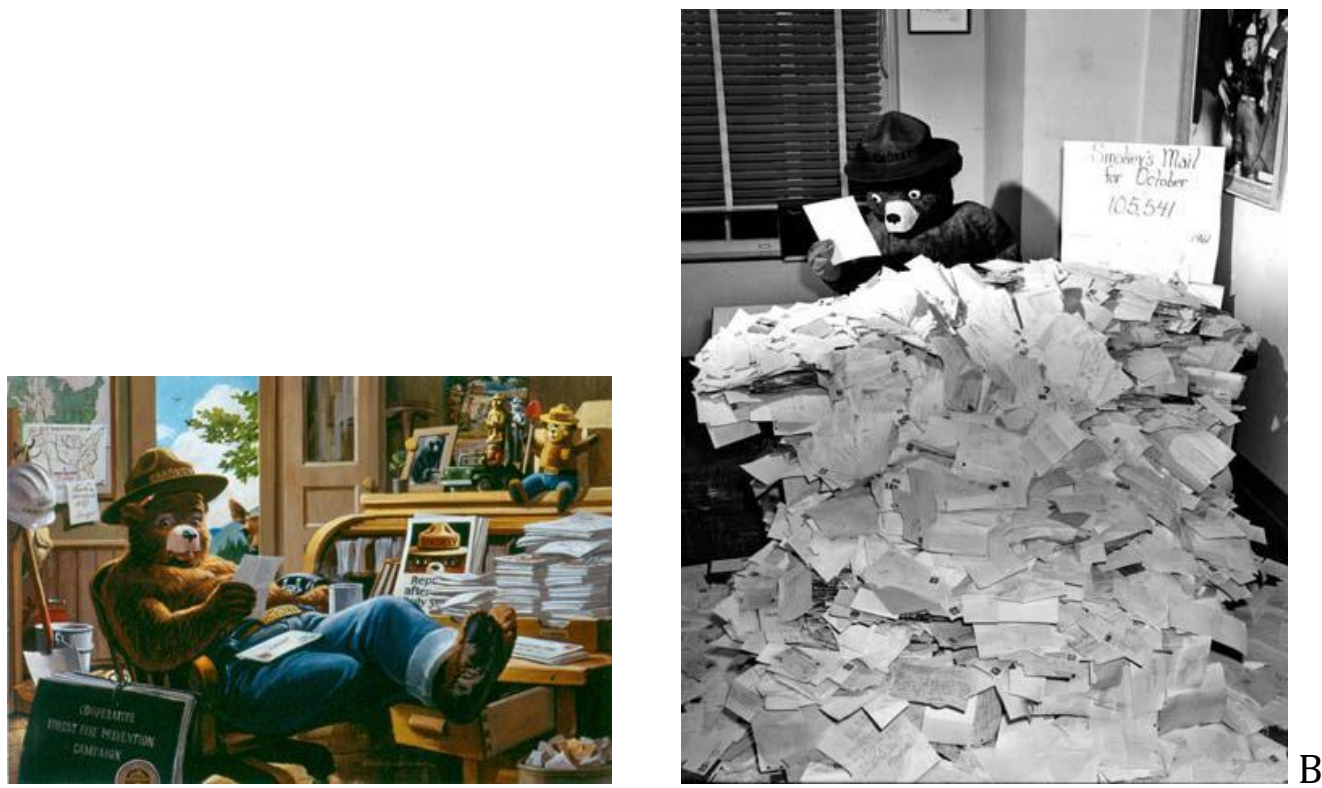

Figure 5: Created to be the friendly face of state land management objectives, Smokey Bear was immediately successful. Fan mail (1979 (A) and 1961 (B)) sent to Smokey Bear was so voluminous that in 1965, the state granted Smokey his own personal zip code.

\section{The Symbolic Colonization of Territory and History}

A repetitive motif in the Smokey Bear campaign has been a symbolic and discursive colonization of territory and history by associating Smokey with iconic landscapes and figures important to U.S. history and identity. In part, such symbolic colonization accomplishes a naturalization of contemporary land management practices by insinuating continuity with their historical antecedents. It also reflects an effort on the part of the state to legitimize its sovereign authority over public lands in North America via the image of a benign protector of the forest. Indeed, once total fire suppression was enshrined in management agency rules and procedures, this policy took on a distinctively nationalist bent. A gigantic Smokey statue was erected in 1954 on the Canadian border, looking north, as a gatekeeper and symbolic manifestation of the United States' nationwide commitment to a particular form of absolutist fire policy (Figure 6). Smokey, standing tall on the U.S. border, bears witness to official attitudes and policies towards wildfire and resource management. Other ads project Smokey's benign oversight to western landscapes by evoking iconic landmarks and popular 
recreational areas, such as Half Dome or the Grand Canyon. The state also made symbolic claims to territory by inserting Smokey into the iconography and material culture of colonized peoples and traditions (Figure 7). As Kosek (2006) observes, such symbolic association ignores and/or erases heterogeneous historical and contemporary land and fire-use practices that remain sources of conflict and tension with federal authorities. Ad Council-produced imagery that depict lands taken by force from indigenous peoples, or that discursively evokes those peoples themselves, originates from and perpetuates state power that is projected over spatial, temporal, ecological, and cultural scales.
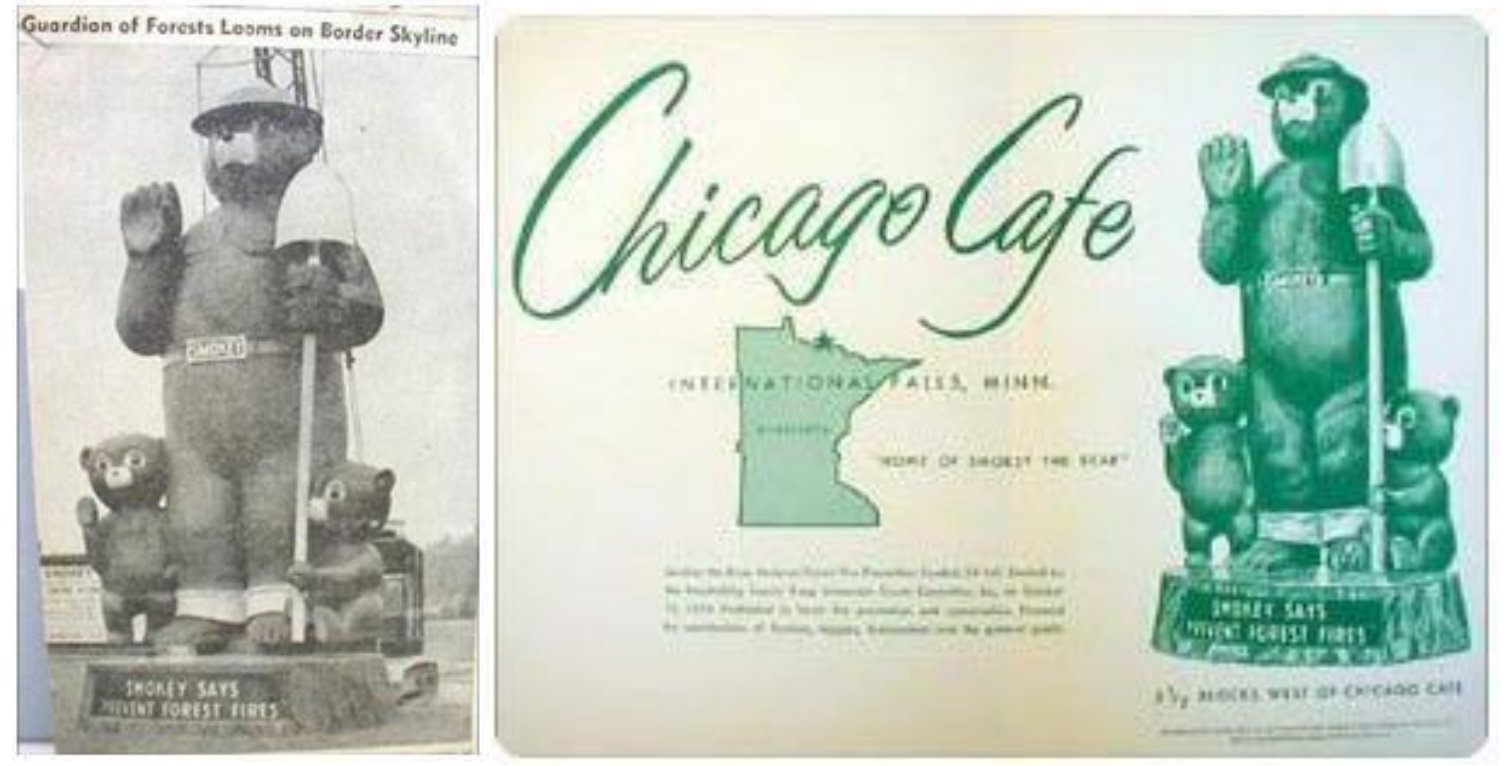

Figure 6: Smokey Bear, as an avatar of US wildfire prevention and rational resource use, was enrolled in territorial boundary making. By positioning Smokey Bear at the U.S.Canada border, the state created a physical embodiment of its fire control policies that were extended over the entire territory behind the bear. 

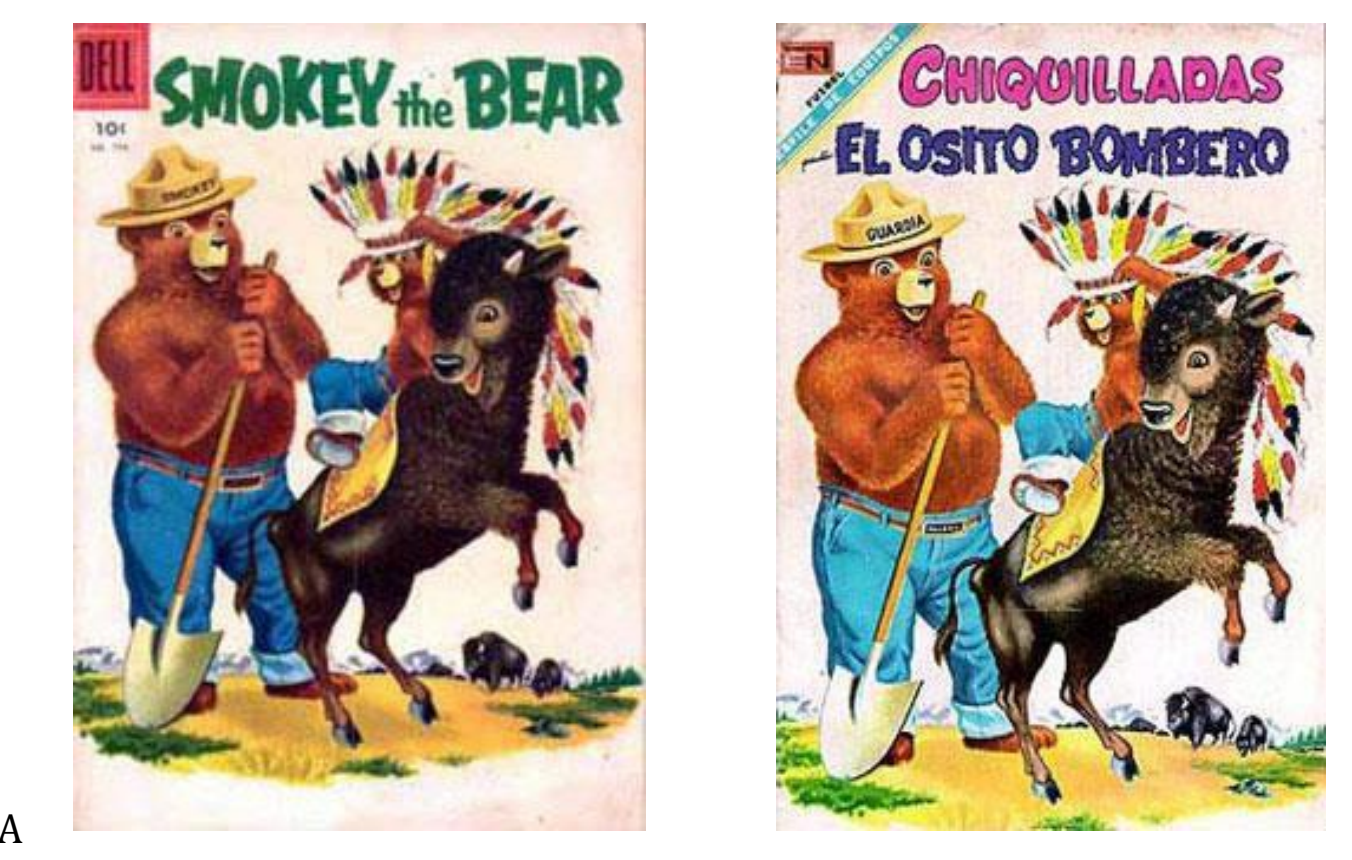

B

Figure 7: Officially-sanctioned commercial products featuring Smokey Bear were used to extend the reach of the wildfire prevention campaign. Through representation of Native American cultural elements (headdress and bison), the state made discursive claims to recently colonized territory and peoples, in the process erasing their longstanding fire use practices. This image (1956), and Figure 3 and the insets in Figure 2, illustrate a sort of thoughtless racism and white supremacy that is projected into east Asia and across North America. In the Spanish version, Smokey's hat reads Guardia (Ranger). What community is the Spanish translation meant to appeal to? These Dell comics ran from 1956-1961, but apparently very few were translated into Spanish. The comics, and a popular 1952 song by country singer Eddy Arnold, created longstanding confusion over whether Smokey is 'the' Bear.

Yet such tensions would seem to be resolved via Smokey's embrace of patriotic bravado accomplished via his anachronistic introduction into proximity with the U.S. "Founding Fathers" (Figure 8) and by bestowing him the honorific: "Great American." These advertisements connect particular forms of fire control with cheerily American iconography - such as the cowboys and yeomen farmers depicted in Figure 9, which are deployed in service to a nostalgic agrarian past that was rapidly receding even as Smokey ads were first being produced. Meanwhile, the conflation of Judeo-Christian morality with wildfire prevention in Figure 10 provides a moral and metaphysical 
underpinning to the state's wildfire prevention program by drawing on taken-forgranted truths and logics familiar to the U.S. public.


A

B

Figure 8: The 1975 U.S. bicentennial saw a series of advertisements that discursively connect Smokey Bear with American history and the mythos of America's Founding Fathers. By anachronistically inserting Smokey Bear into U.S. history, the state attempted to impart a longer temporality to its fire control policies than was factually true, while simultaneously drawing on patriotic sentiment.

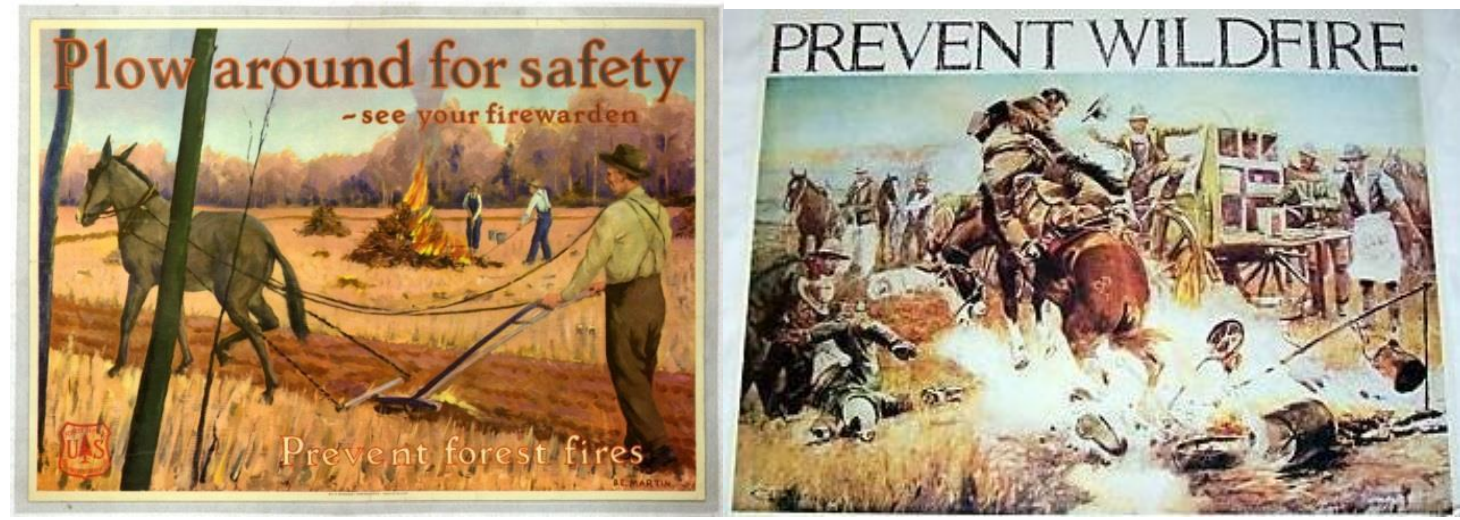

Figure 9: A series of similar posters evoke nostalgia for America's agrarian past, even as the country was rapidly industrializing and formerly rural spaces were filling up with housing developments. This represents a process of territorializing history, in parallel to associated efforts that discursively territorialize space, culture, and people. 

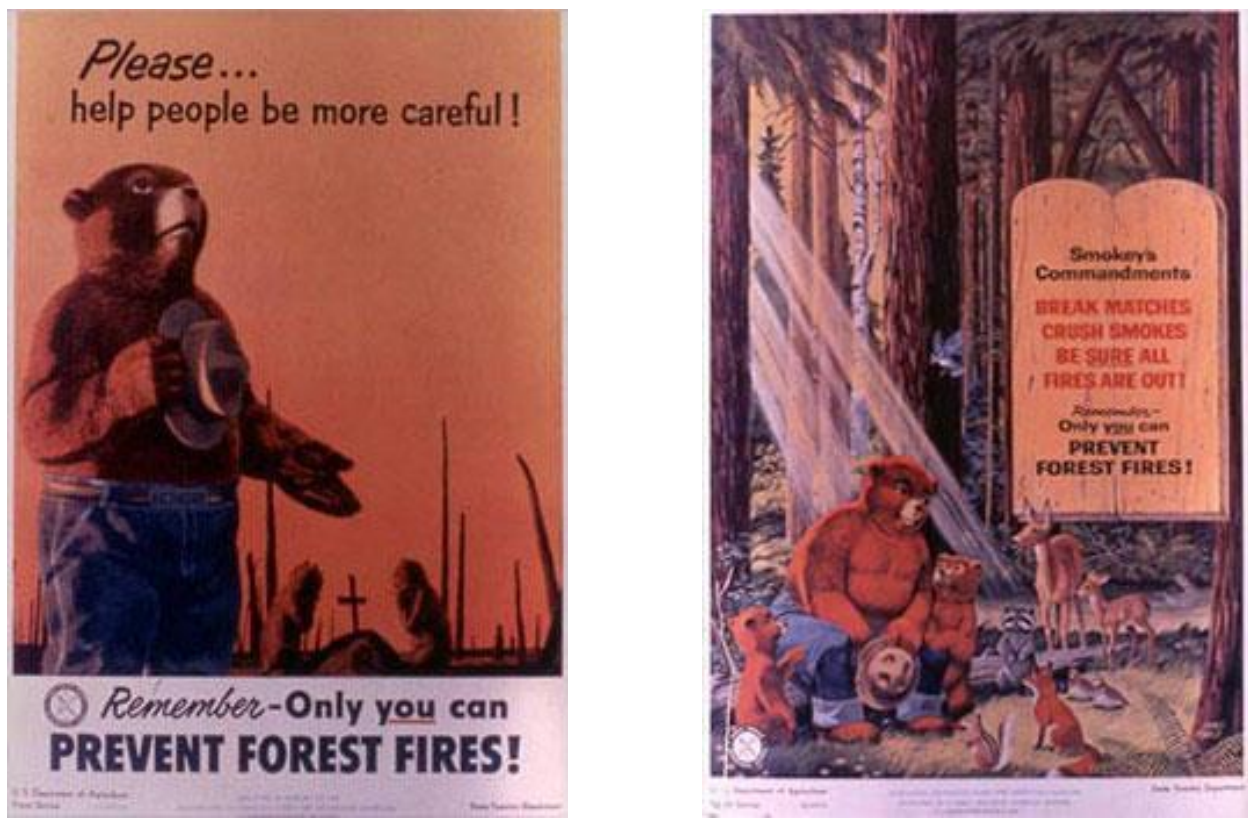

B

Figure 10: Conflation of U.S. wildfire prevention with Judeo-Christian morality served to reinforce the dominant American culture by aligning it with self-evidently beneficial state management of fire and resources and providing this with an easily- recognizable metaphysical foundation.

Deploying religious symbology and imposing contemporary attitudes about fire use onto American history imbues a sort of timelessness into practices and policies that emerged from a specific moment in history and a particular political ecology of forest governance. Thus U.S. management practices are projected backward, eliding and obscuring many centuries of fire use by settlers and native peoples that shaped and defined ecosystem dynamics and bear no resemblance to the total suppression policies embraced during the $20^{\text {th }}$ century. Smokey Bear, then, provides the state with a flexible medium through which to visually connect state sovereignty, expressed through claims to territory and history, to particular forms of land management.

\section{Smokey and the Cultivation of a "Proper" Fire-Using Citizenry}

As the Smokey Bear campaign evolved, he continued to peddle a distinctly militaristic symbology. By the 1960s this reflected the preoccupation of the American public with the Cold War and associated anti-communist paranoia. For example, "Bomb in the 
Forest" (1969) is a TV spot that shows seven hydrogen bomb test explosions timed to coincide with a bell tolling with funereal slowness, while a voiceover relates the area burned in the previous year $\left(10,000 \mathrm{mi}^{2}\right)$ to the destructive power of 90 hydrogen bombs. Deliberate connections to Cold War themes are also evident in a 1983 poster, which features a red telephone evocative of popular culture imaginaries of the 'Hot Line' between the White House and the Kremlin (Figure 11). In no small way, the insertion of Cold War symbolic and discursive elements conflating arson and nuclear war once again communicates that uncontrolled ignition is not just a menace to U.S. forestlands, but an existential menace both to the forest and to the wellbeing of the nation. Happily, though, it is a menace that each individual can help hold at bay, through the careful monitoring and control of his or her own conduct.

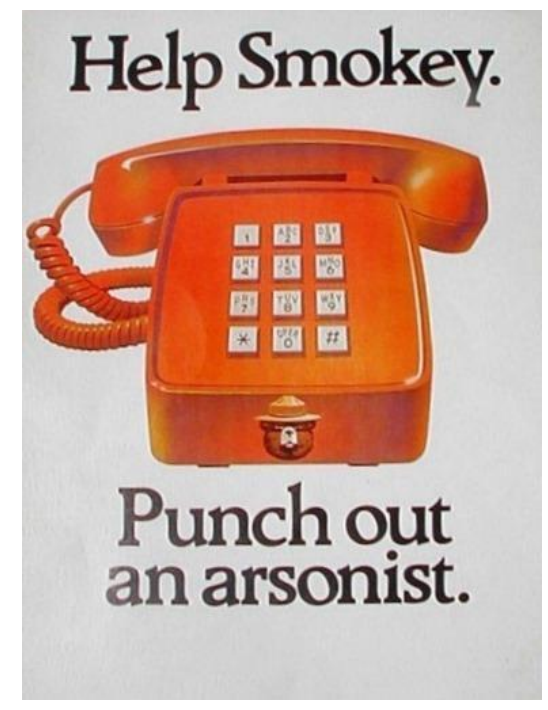

Figure 11: Cold War paranoia is evident in this 1983 poster, which subliminally draws parallels between forest fire and global nuclear annihilation. Cold War themes echo the military themes that have been prominent in the wildfire prevention campaign since its inception.

Throughout the latter half of the $20^{\text {th }}$ century the basic contours of this message persisted even as its audience underwent substantial changes as an outcome of the civil rights revolution of the 1960s and broader shifts in the nation's values, aspirations 
and demographic composition. Until the mid-1970s wildfire prevention advertisements featured entirely white figures and characters. As Kosek (2006: 214) argues, even Smokey Bear is arguably white, judging by his voice in radio and television spots and his particular and peculiarly racialized history. Evolving political and demographic trends did however lead to the eventual creation of wildfire propaganda that depicted or gave voice to non-white subjects. In Figure 12, a deliberately multicultural American public is depicted as potential ignition sources lined up shoulder to shoulder in a paper matchbook.



Figure 12: Still image from TV spot "Matchbook" (1974) which displayed a deliberately multicultural America that differed starkly from the portrayals of woods and resource users extending to the earliest wildfire ad campaigns. Subtle shifts in the composition of wildfire prevention media mirrored ongoing transformation of U.S. culture.

The use of non-white voices and characters in the wildfire prevention project has become more common in recent years, corresponding to an 'urban turn' in the Smokey campaign. 2011's television spot "Neighbors" plays up a confrontation between two suburban neighbors: a white man who leaves a pile of leaves burning in his subdivision lawn, and an African-American neighbor who lectures him on his inattention in a slangy accent. This advertisement ends with the black neighbor reciting a statistic about humancaused ignitions in his normal voice, before Smokey Bear ends the ad in a deep, gravely, country-western drawl. "Neighbors" in fact reflects only the second advertisement featuring authentic African-American voices, the first beingan 
experimental Ray Charles television ad developed in 1983 wherein against the visually impaired musician talks about his experiences listening to forest sounds against an entirely blank screen. Although the Smokey Bear campaign did not discursively incorporate non-white citizens as potential threats to forests until well after the height of the U.S. Civil Rights movement, media produced at the nexus of the state and the advertising industry did eventually adjust to evolving national conceptions of citizenry and belonging.

Wildfire prevention advertisements also tracked the rise of the environmental movement, featuring bucolic rural scenes with intact ecologies (Figures 13-14), rather than infernos and blackened forests. By the 1970s well-publicized environmental disasters, including ozone depletion, acid rain, lead exposure, air quality issues, and early hints of global warming had begun to emerge alongside a newfound environmental consciousness and activism. Radio and TV spots echo this shift towards environmental awareness and an expanded environmental ethic, as demonstrated in a TV spot titled "Do Trees Think?" (1989). A narrator breathily asks, over the sound of flutes and windchimes, "Do trees think? Can plants life feel? Do they fear fire? If they do, they're not alone. More people are moving to our forests, so be careful with fire: you could hurt a lot more than trees." The taken-for-granted logics of environmentalism are not divorced from complementary threads in American culture, such as gendered and racialized paternalism. Figure 13 illustrates this dynamic clearly through its subject matter: Smokey Bear rendered as a soft-featured father figure, cuddling and comforting a menagerie of baby animals that are clustered between two fir seedlings. Smokey, in this iteration, is a protector of the forest and its vulnerable inhabitants in much the same way that contemporary American culture imagined masculine gender roles. Meanwhile, Figure 14 literally shows Smokey Bear hugging a tree, offering a visual representation of a powerful trope in the U.S. environmental movement. Echoing Garmany's (2010) articulation of governmentality, the Smokey Bear campaign harnesses internally logical discursive categories of an emerging environmental consciousness, while subtly recalling deeply embedded cultural 
touchstones. In this way, wildfire prevention media were able to maintain consistent focus on state objectives while altering superficial elements of the campaign.

\section{Remember: there are babes in the woods.}

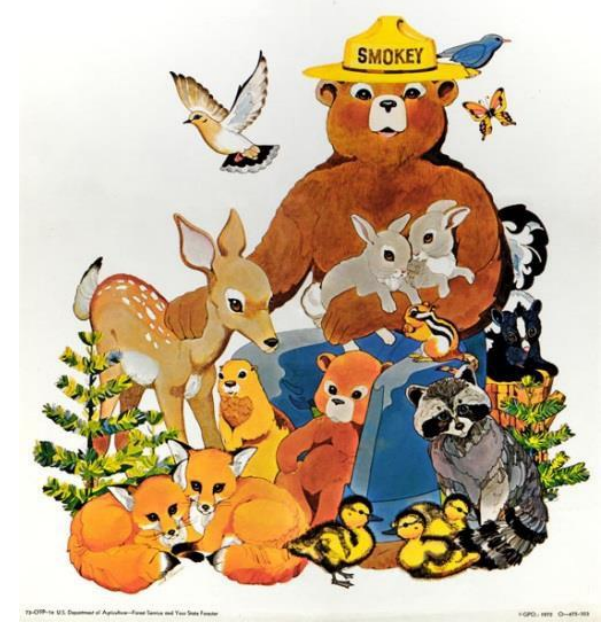

Figure 13: In comparison to earlier posters that depicted ecological destruction and conflagration, environmental movement-era posters featured species, habitat, and intact landscapes. The rise of the U.S. environmental movement carried with it vestiges of paternalism and the gendered history of Smokey Bear.

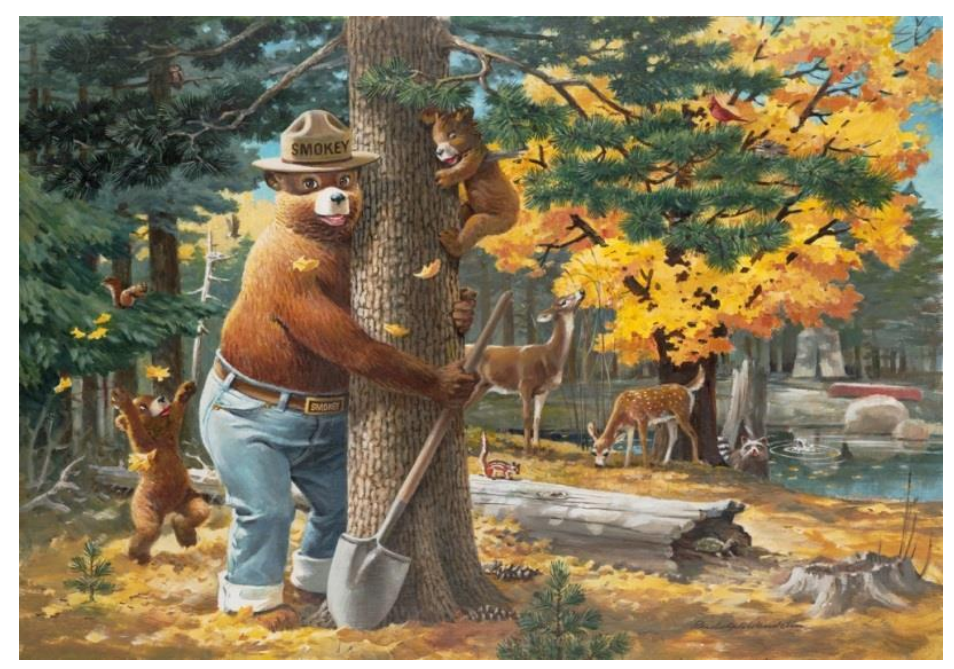

Figure 14: U.S. environmentalism is often imagined through the lens of bucolic, parklike recreational landscapes. Many wildfire prevention advertisements from this era contained images of recreational use of federal lands, such as boats, tents, and picnicking families. 
Over the course of 70+ years, Smokey's central moral, inexorably tied as it is to taken-forgranted logics of forest health, became so deeply internalized by a media- consuming public that by the 1970s and 1980s that the Forest Service and Ad Council could truncate and elide Smokey's full message without sacrificing its meaning. In

Figure 15, Smokey's iconic slogan is abbreviated to its essential element: "Remember, Only YOU," and “Only YOU,” while Smokey's accusatory finger, pointed generically atan anonymous reader, renders clear his meaning: it is each and every individual in the United States, through the carelessness or carefulness of his or her behavior, who bears ultimate responsibility for ignition and acreage burned on the nation's forest lands. This represents a striking success in the deployment of mass media to manipulate popular conduct to support the state's landscape management agenda, and illustrates the process of governmentality through which state goals are accomplished through the self-regulation of its citizenry. Indeed, Figure 16 suggests that by 1988 the Ad Council and the U.S. Forest Service were so unambiguously impressed with Smokey's accomplishments that they awarded him a gold medal. Considering the image's site of production, Figure 16 illustrates a retrospective and reflexive selfcongratulation on the part of the Ad Council and the state. It is no coincidence that at the same time that Smokey was enjoying self-referential accolades, and when his message was so irresistibly present in the minds of the U.S. public that it could be abbreviated without loss of function (Figure 15), wildfires were at their historical nadir (Westerling et al., 2006; Abatzoglou \& Williams, 2016). But as time passes and fuels accumulate in the forest, the material consequences of "success" have become increasingly unbearable, demanding renewed and ever-increasing attention from the state in a project of fire and forest management that still deploys Smokey Bear as its most public messenger. 

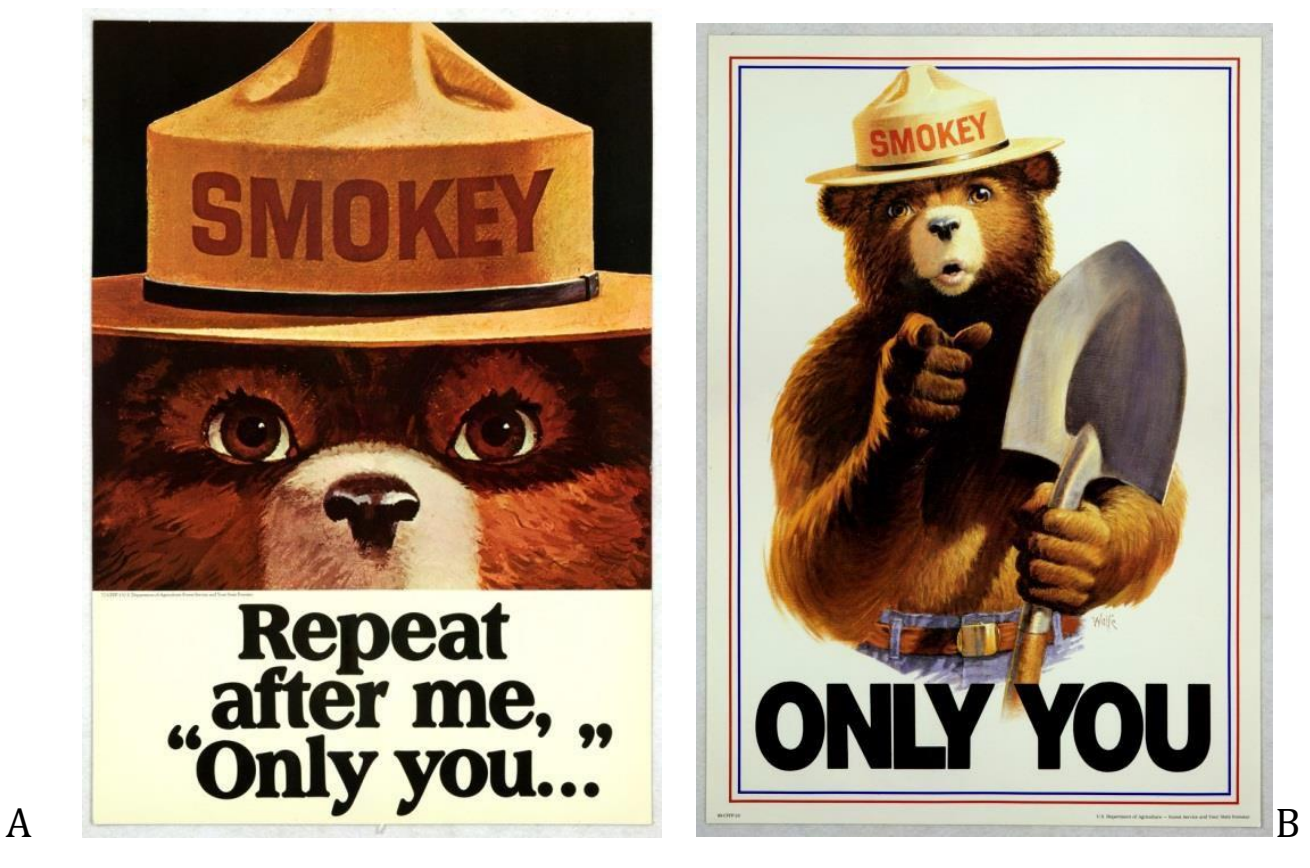

Figure 15: By the late 1970s, the message and motivation of Smokey Bear had been so ingrained in the national consciousness that Smokey's tagline "Only You Can Prevent Forest Fires" could safely be elided to this truncated phrase. Smokey's central message was so successful that the state could count on ad viewers to fill in the missing words, and to govern themselves accordingly.

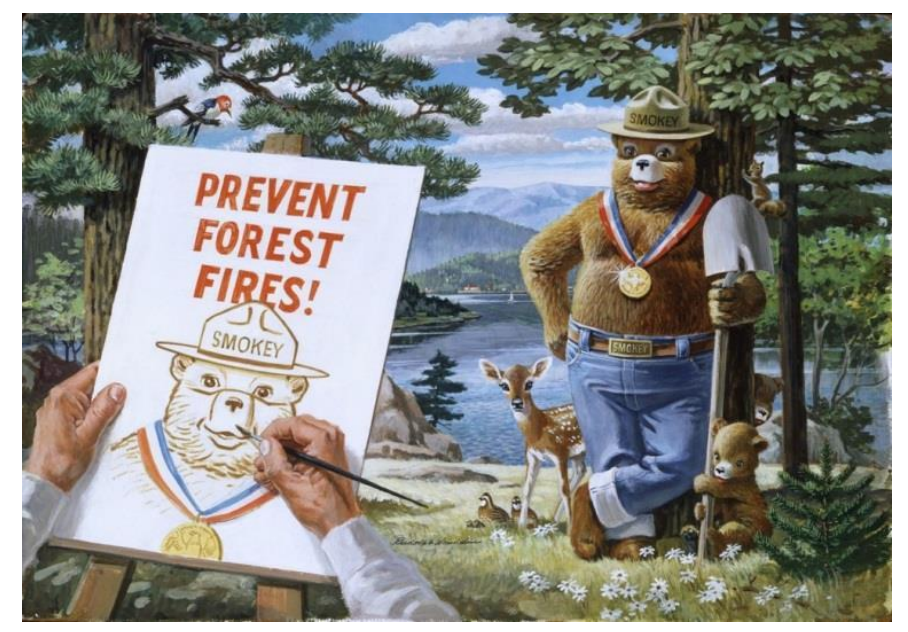

Figure 16: In this 1988 poster, the state appears to be congratulating itself on a longrunning and successful advertising campaign, even as changes to forest structure and fuel loads were making prevention and suppression of wildfire an ever more Sisyphean task. This poster is unusual in that it breaks down the $4^{\text {th }}$ wall and depicts a wildfire prevention ad in the making. In the process, this poster illuminates the site of production of wildfire prevention media, which occurs at the intersection of the U.S. state and the advertising industry. 


\section{Blowback: Fire Control and the Material Transformation of U.S. Forestlands}

Reviewing the more than seven decades of the Smokey Bear campaign, we have argued that in the United States citizenship, nation and territory have been constituted, at least in part, through managing the relationship between the forest and its imagined Other: fire. Indeed, it was in the interest of fire prevention that the state first sought to intervene in popular attitudes and behavior in order to control an enemy that was at once represented as foreign to the forest but internal to the citizenry - and that could therefore only be contained through the proper conduct and disciplined behavior of a forest-using public. Importantly, the general features of this campaign remained flexible and responsive to profound shifts in the values, aspirations and demographic composition of the U.S. nation, even as the core tenets of this message remained more- or-less unchanged - thus allowing for the enrollment of a newly-expansive polity into the fire prevention enterprise. As wildfire prevention media depicted new people and places, the underlying enterprise of technocratic and intensive sovereign state management of wildfire remained unchallenged.

In many ways, the fire prevention advertising campaign personified by Smokey Bear is illustrative of Michel Foucault's concept of 'governmentality,' which he describes as an evolving array of power whose origins lie in Medieval and early-modern pastoral and confessional practices; and whose logic is oriented not so much toward "political structures or the management of states," (Foucault, 1982; 790) but rather those "mechanisms" through which "one can direct, in a fairly constant manner and with reasonable certainty, the conduct of others" (ibid.; 794. See also Foucault, 2007; 192- 193). Yet it bears emphasis that in the case examined here, the object of the state's intervention is never really the conduct of the population itself; rather their attitudes and behavior were and are instrumentalized toward a particular set of environmental management outcomes, which are themselves coupled with a military and colonial project of extractive resource management and state territorialization in North America. The above complicates a binary reading of the state and subject - with landscape as a third, its non-human composition both an object and means of 
territorialization for which the citizen-subject is neither irrelevant nor the precise target of intervention.

This then suggests the purchase of mobilizing Foucaultian concepts like "governmentality" and "biopolitics" beyond a strict focus on human beings and their conduct, to an examination of how humans and non-humans may be operationalized as a coupled assemblage in the context of state intervention. Indeed, this is not so far from the direction toward which Foucault himself gestures in his 1975-1976 lectures at the Collège de France, suggesting that “[b]iopolitics' last domain is ... control over relations between the human race, or human beings insofar as they are a species, insofar as they are living beings, and their environment, the milieu in which they live. This includes the direct effects of the geographical, climatic or hydrographic environment..." (Foucault, 2003: 244-245). Philo nicely summarizes Foucault's argument, asserting that "what appears in his lectures are now milieu... full of lively, risky, unpredictable 'stuff' whose co-incidental juxtapositions can release all manner of disruptive effects" (Philo, 2012: 508). U.S. forestlands in the $21^{\text {st }}$ century are exemplary of this disruptive possibility, and yet the ways that this 'unpredictable milieu' may come to affect state practice merit greater attention.

It is here that we return to the dis/continuities in the Smokey Bear campaign, by which we mean the divergence between the transformation of scientific knowledge and U.S. land management practices, on the one hand, and the consistency of Smokey's message in the face of these changes, on the other. We believe that an explanation for these dis/continuities can be found in the biophysical transformation of U.S. forests and of

U.S. residential settlement patterns - changes for which Smokey bears some responsibility. These changes are well documented in the established literature on fire ecology and environmental history (Pyne, 1982; 1997; 1998; 2001; Dods, 2002; Donovan \& Brown, 2007; Collins, 2008; Marlon et al., 2012; Simon, 2014; 2016), so here we highlight the most important relationships. We begin with the forest.

Over the course of its decades-long lifespan, the United States government attributes to the Smokey Bear wildfire prevention advertising campaign a $40 \%$ reduction in wildfire 
events, resulting in a decline from 22 million to 8.4 million acres burned annually (USDA Forest Service, 2004; Ad Council, 2016). ${ }^{1}$ Indeed, despite recent claims by the U.S. Forest Service that 2015 saw the greatest acreage burned since recordkeeping began, early wildfire prevention advertisements cited annual burning at 30 million acres (Figure 17). But the consequences of decades of fire prevention and suppression set into motion a host of unruly forest dynamics that present myriad challenges to those state agencies tasked with controlling and containing fire-related hazards to life and property.

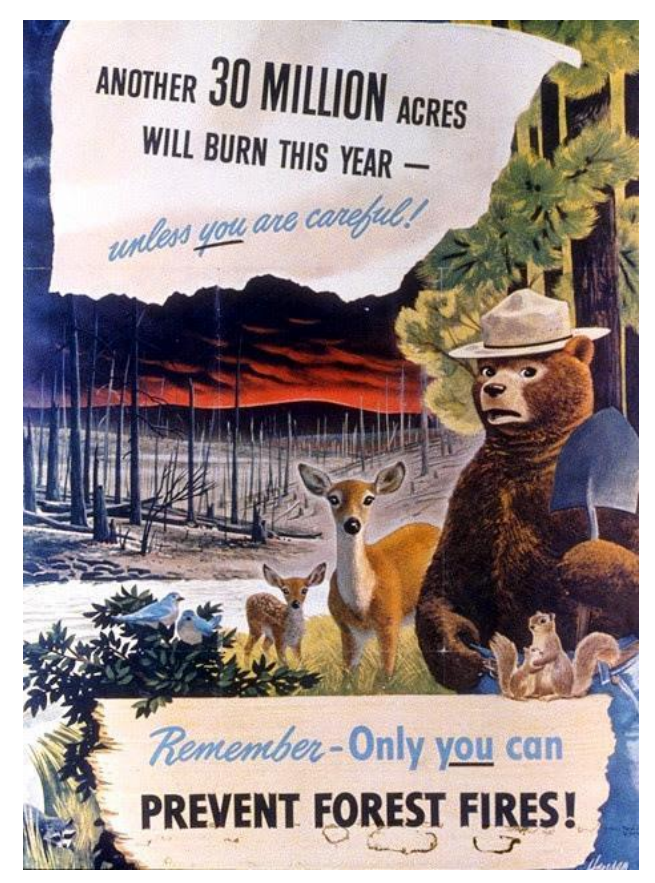

Figure 17: Despite recent claims that contemporary fire sizes and overall area burned are higher now than in the past, historical wildfire prevention posters from the 1940s and early 1950s report very extensive annual burning. As with contemporary wildfires, the state demonstrates a recognition that anthropogenic ignitions affect a sizeable proportion of the area affected (1948).

${ }^{1}$ The U.S. Forest Service has long correlated forest users with ignitions, going so far as to credit the Smokey Bear campaign with reducing 1956's burn extent from a potential 58 million acres to the 8.8 million acres that actually burned (Grant, 1957). This estimate was arrived at by correlating the fire rate to the number of forest users before the advent of Smokey Bear, and subsequently estimating how much fire would have been expected from a greater number of forest users who are axiomatically viewed as potential ignition sources. 
At the turn of the $20^{\text {th }}$ century U.S. land management agencies inherited landscapes that were reasonably resilient to wildfire, especially the surface fire regimes characteristic of many ecosystems as they entered federal management. As described above, these landscapes were the product of millennia of fire use by indigenous peoples and later European settlers whose land use practices were largely compatible with aboriginal fire regimes. As an outcome, early fire suppression efforts were remarkably successful, even with modest expenditures of labor and money. But the inevitable combined effects of fire prevention and suppression was a slow buildup of unburned fuels, encroachment of woody plants into grasslands, and other dramatic structural changes to forest ecology. Donovan \& Brown (2007: 73) catalogue some of these outcomes, which include a shift to less firetolerant species; increases in stand density and forest stocking rates; increases in the amount and spatial distribution of flammable fuels; and an intensification in fire behavior, which is often followed by additional changes to vegetation communities. In turn, these changes to forests require the state to intensify its response to ignitions, and to expend ever-greater resources on fire suppression activities.

At the same time, the expansive growth in U.S. population centers; the demographic transfer of the U.S. population toward the Sunbelt and the Mountain West; and a taken-forgranted belief, promoted for decades by Smokey Bear, that fire is an alien interloper in the forest, have all contributed to a monumental increase in what has come to be known as the wildland-urban interface, or "the area where houses meet and mingle with undeveloped wildland vegetation" (Glickman \& Babbitt, 2001). Indeed, based on a mapping of census blocks and fine-resolution vegetation data, Radeloff et al. (2005) estimate that this zone today contains 44.8 million homes, or fully $39 \%$ of all housing units in the United States.

The combined outcome is that fires are more likely to ignite; more likely to burn at higher intensity; more likely to cause long-term harm to human life, property and forest health; and much more difficult and expensive to fight. As a result, wildfire suppression costs have crept up and the balance of management agency personnel has tipped towards fire-related staff over other functions, representing what we believe is 
a novel form of agency capture driven by an ecological disturbance process that is itself an artifact of state intervention (Clarke \& McCool, 1996). Indeed, as of 2015, a majority of U.S. Forest Service personnel are in fire-related positions, and more than half the Forest Service's budget is devoted to fire suppression; projections of budget allocations predict that as much of $2 / 3$ of the Forest Service's budget could be consumed by fire management in the next decade (USDA Forest Service, 2015). Yet, exacerbated by climate change and the continuing buildup of fuel loads, catastrophic wildfires continue to rage across the western United States, causing acute damage to property, ecosystem health and human life.

Various measures have been introduced to try to control these hazards. The 2000 National Fire Plan and 2003 Healthy Forests Restoration Act both provided additional resources for fire suppression and post-fire recovery, and for fuel reduction through prescribed burn and mechanical removal. But fuel reduction strategies require a considerable investment of money, planning, equipment and personnel - either to control and mitigate the hazards of prescribed burn or to physically remove huge quantities of organic material from a forest area (Busenberg, 2004). In no small measure, then, the decades-long buildup of fuels that occurred under Smokey Bear's watchful gaze has created fires that cannot be suppressed without tremendous expenditure of labor and public treasure - and some contemporary fires cannot be safely or successfully suppressed but instead burn until they run out of fuels or reach impermeable firebreaks. The contemporary wildland fire crisis is at once a result of state practices that combine direct fire suppression and indirect attempts at governing fire practices of the populace, and it requires ongoing and accelerating investments in fire control as flammable landscapes refuse to submit to state power.

In a sense, then, although it is the argument of this paper that we cannot understand the material composition of contemporary forest and fire dynamics in the United States independent of Smokey Bear and the policies he represents, the forest and its propensity to burn must also be understood as a driver of contemporary state practice and the intensification of intervention strategies over time. In other words, rather than merely an effect of the state, or an expression of what Painter (referencing Hirsch 
[1983]) calls a process of "statification" (in which "the state apparatus extends deeper into the social organism and connects closer to the social structure" [Painter, 2006: 753]), we might rather consider the North American forest as a vector of state power - a space of intervention driving non-linear environmental changes that generate a need for additional fire management resources, which further transform forest ecology, which then demand additional state intervention, and so on. Smokey Bear has been and remains a key medium for mobilizing and enlisting the public's participation in this vector of state power - not merely as an ideological effect, but as a material assemblage that requires ongoing state intervention to avoid a catastrophe whose conditions of possibility it has itself produced.

\section{Conclusion: Pyropolitics and the Combustible Dimensions of Collective Life}

The Smokey Bear campaign has not eased from its emphasis on fire prevention, even as a number of federal and state management agencies have shifted funds and efforts into prescribed fire, 'let burn' policies in wilderness and remote areas, and strategies that allow fire to burn for the benefit of various resources. Yet the U.S. Forest Service and Ad Council have entered at least one small change to Smokey's iconic message: in 2001, Smokey's tagline was edited from "Only you can prevent forest fires" to say "Only you can prevent wildfires" (emphasis added), reflecting the agency's changing management practices, along with an increasing concern with fires burning in non-forested ecosystems including the volatile and politically complicated wildland-urban intermix (Cohen, 2008). Yet while Smokey Bear advertisements have themselves remained essentially unchanged in their message of total fire prevention, a more nuanced understanding of wildfire is available from Smokeybear.com, a website jointly managed by the Ad Council and the U.S. Forest Service. This website contains information on the benefits of natural fire rotation, firedependent ecosystems, the legacies of indigenous fire use, discussion of the efficacy of prescribed fire, and a forthright discussion of why fire severity and intensity is increasing. They attribute amplified fire effects to the legacy of decades of fire suppression policies, in 
conjunction with climate change, more severe fire weather, and housing development in fire-prone environments. Despite this clear-eyed assessment that recent changes to wildfire size and severity are owed in part to Smokey's own legacy, the website concludes with a reassertion of the legitimacy of Smokey's message by posing the question "Is Smokey Wrong?" The website simply answers: "No."

In part, Smokey Bear's message can remain consistent in the face of dramatic environmental change precisely because of his focus on fire prevention rather than suppression. Even as the U.S. fire control apparatus moves away from total fire suppression policies and begins to restore fire to diverse landscapes across North America, Smokey Bear can still push his message of ignition prevention because Smokey's message sounds innocent and logical: by preventing unauthorized ignitions, fire can remain wisely managed by the technocratic expertise of the state. But the apparent logic of ignition prevention only makes sense if we ignore the environments produced and maintained by anthropogenic fire regimes. By discursively projecting Smokey Bear back into American colonial history and across North American ecosystems, the U.S. wildfire prevention campaign erases human contributions to fire regimes and successfully reinforces contemporary fire policies as the wisest possible course of action.

The durability and immutability of Smokey's message in the face of intractable ecological change would appear paradoxical were it not made legible via simultaneous attention to those more-than-human forces and conditions that have responded to governmental intervention over time, but in ways both unanticipated and difficult to control. Thus, even as the U.S. fire control apparatus has adjusted to respond to novel conditions and growing scientific understanding of those conditions, techniques of governance targeting the fire practices of the lay public remain essential for controlling and curbing when and where ignition occurs. In this sense, Smokey Bear and his media campaign still plays a central role in the U.S. fire control apparatus because of how state power is expressed in these morethan-human pyropolitical entanglements. In the case of wildfire, successful implementation of governmentality involves simultaneous discursive claims over territory, history, cultural elements, and aboutthe 
central role of the state as the central repository for fire management knowledge. Smokey's message does not need to change, because although ecological conditions and disturbance severity are radically different than at the advent of formal fire suppression policies, the state is successfully positioned as the only viable actor for fire control and fire use.

Of course, the approach to fire governance adopted by the United States and personified by Smokey Bear is not the only possible model for managing fire-prone landscapes and human use of and habitation therein. Certainly, there are many examples of fire suppression within colonial and postcolonial contexts (Kull \& Laris, 2009; Kull, 2004; Mathews, 2003). Yet around the world, various "publics" maintain heterogeneous relationships with fire that are sanctioned or tolerated by state officials (Nigh \& Diemont, 2013; Eriksen, 2007; Kull, 2002). As Pyne (1998) points out, in Australia - another fire-prone settler colonial context - state officials remain eager to foster the participation by rural inhabitants in controlled burning (itself a policy that is heavily contested - see Buizer \& Kurz, 2016; Edwards \& Gill, 2016).

Nevertheless, it is toward a study of such heterogeneous fire regimes and the ways these become entangled with questions of citizenship, territoriality and environmental change that we have sought to signal with use of the term "pyropolitics." Taking a cue from Clark (2011), we have argued here that by centering combustion and its governance in our approach to politics and collective life, we may obtain novel insights into the complex entanglement of state power with the material multiplicities in and through which it is exercised - along with the ways that these continuously act and react over time, changing in surprising and unanticipated ways that in turn drive novel strategies and practices of intervention to respond to material conditions as these evolve.

Unpacking the generative and recursive dynamics set in motion by those non-human targets of governmental intervention reveals an important temporal quality to their articulation with state practice. On the one hand, this suggests that by displacing and suppressing previous fire regimes what have also been displaced and suppressed are 
previous and alternative forms of collective life, and the political ecologies that subtend these - a point so elegantly illustrated by Kosek (2006) in his ethnographic examination of the anger and resentment leveled at Smokey Bear by rural forest users in northern New Mexico. Much more could be written on the intersections of fire control with historical geographies of dispossession, in North America and beyond. For example, writes Dods (2002: 476):

"The Smokey campaign was remarkably successful. It represents a mindset associated with mythic forests of the past in which the wilderness was unmanaged, and in which forest fires were an unmitigated ecodisaster. With few exceptions and until quite recently, it obscured the recognition that the past and present 'wilderness' comprised many types of managed, cultural landscape. Of course the recognition of these means the recognition of a myriad of troublesome ideas - ideas about original ownership and all that this could, would and should entail."

On the other hand, this also suggests an ethical and political responsibility toward the future. There are promising intersections here to be explored with literature on risk and governance (Olson et al., 2017; Simon, 2014; Collins, 2008; Tàbara, Saurí \& Cerdan, 2003) which, approaching the problem from a different angle, have also been expressly concerned with the kinds of political-cultural-biophysical feedback loops considered in this paper. And of course, a research agenda that would tackle the temporal qualities of collective life and its more-than-human articulations has implications for questions of power and combustion (including its internal variants), whose implications are global and geologic in scale - and with whose long-term, nonlinear consequences we are only beginning to conduct a reckoning (Clark \& Yusoff, 2014; Mitchell, 2011). Indeed, Smokey provides merely one window into the co-articulation of state, citizenship and combustion, and this remains a salient area of inquiry that can mobilize posthumanist thought, environmental history and scientific understanding of ecosystem dynamics as critical components of political geographic scholarship.

Reviewing a selection of U.S. wildfire prevention advertisements, we have examined the ways that this media campaign contributes to a materialization of citizenship, territory and environmental policy through the mutable ecology of North American 
forestlands. The above includes a host of unruly, pyrogenic ecosystem dynamics that finally drive and demand additional state intervention in order to mitigate the accelerating threat of large and severe wildfire, and Smokey Bear continues to play a distinguished role as a preferred symbol and medium of this landscape management agenda. Our paper concludes here with the suggestion that political geographers pay greater attention to combustion and its governance as a constitutive, if heterogeneous, dimension of modernity and collective life. Pursuit of such an agenda promises important insight into the temporal and geographic articulation of state power with the more-than-human multiplicities in and through which it is exercised - including the quotidian, unexpected and nonlinear ways that the biophysical realities of terrestrial space not only respond to, but also drive, shape and condition particular regimes of governance.

\section{Funding}

This research did not receive any specific grant from funding agencies in the public, commercial, or not-for-profit sectors.

\section{Acknowledgements}

We would like to thank Dr. Thomas Swetnam for access to his extensive private collection of wildfire prevention posters, which includes numerous excellent examples that have inspired and informed the arguments developed in this paper. In her capacity as a discussant at the 2016 annual meeting of the Association of American Geographers, Pavithra Vasudevan provided very helpful comments on an early draft of the manuscript. We also thank three anonymous reviewers who offered constructive feedback and helped us to clarify and strengthen the paper.

\section{References}

Abatzoglou, J. T. and Williams, A. P. (2016). Impact of anthropogenic climate change on wildfire across western US forests. Proceedings of the National Academy of Sciences, 113(42), 11770-11775.

Ad Council (1960). The True Story of Smokey Bear. Western Publishing Company, USA. http://www.wvforestry.com/comicbook.pdf. (Accessed 8 August 2016). 
Ad Council (2016) “Wildfire Prevention 1944-Present: Overview." http://www.adcouncil.org/Our-Campaigns/The-Classics/Wildfire-Prevention (Accessed 8 August 2016).

Boyce, G. A. (2016). The rugged border: Surveillance, policing and the dynamic materiality of the US/Mexico frontier. Environment and Planning D: Society and Space, 34(2), 245-262. http://dx.doi.org/10.1177/0263775815611423

Braun, B., \& Whatmore, S. (2010). "The Stuff of Politics: An Introduction" in Political Matter: Technoscience, Democracy, and Public Life. B. Braun \& S. Whatmore (Eds). Minneapolis, MN: University of Minnesota Press.

Busenberg, G. (2004). Wildfire management in the United States: the evolution of a policy failure. Review of policy research, 21(2), 145-156.

Buizer, M., \& Kurz, T. (2016). Too Hot to Handle: Depoliticisation and the discourse of ecological modernization in fire management debates. Geoforum 68, 48-56.

Carle, D. (2002). Burning questions: America's fight with nature's fire. Westport, CT: Praeger.

Clark, J., \& Jones, A. (2016). (Dis-)ordering the state: territory in Icelandic statecraft. Transactions of the Institute of British Geographers, 42(1), 123-138. http://dx.doi.org/10.1111/tran.12154

Clark, N. (2011). Inhuman nature: sociable life on a dynamic planet. Sage Publications.

Clark, N., \& Yusoff, K. (2014). Combustion and Society: a fire-centred history of energy use. Theory, Culture \& Society, 31(5), 203-226.

Clarke, J. N., \& McCool, D. (1996). Staking out the terrain: power and performance among natural resource agencies. Albany: State University of New York Press.

Cohen, J. (2008). The Wildland-Urban Interface Fire Problem: A consequence of the fire exclusion paradigm. Forest History Today, https://www.fs.fed.us/rm/pubs other/rmrs 2008 cohen j002.pdf.

Collins, T. (2008). The political ecology of hazard vulnerability: Marginalization, facilitation, and the production of differential risk to urban wildfires in Arizona's White Mountains. Journal of Political Ecology, 15, p. 21-43.

Cooperative Forest Fire Prevention Program, US Department of Agriculture. (2011). "Smokey Bear Guidelines." www.smokeybear.com/resources/Smokey Bear Guidelines.pdf (Accessed 20 May, 2016). 
Dittmer J. (2013). "Geopolitical Assemblages and Complexity" Progress in Human Geography, 0309132513501405.http://dx.doi.org/10.1177/0309132513501405

Dods, R. R. (2002). The death of Smokey Bear: the ecodisaster myth and forest management practices in prehistoric North America. World Archaeology, 33(3), 475487. http://dx.doi.org/10.1080/00438240120107486

Donovan, G. H., \& Brown, T. C. (2007). Be careful what you wish for: the legacy of Smokey Bear. Frontiers in Ecology and the Environment, 5(2), 73-79. http://dx.doi.org/10.1890/1540-9295(2007)5[73:BCWYWF]2.0.C0;2

Edwards, A., \& Gill, N. (2016). Living with landscape fire: Landholder understandings of agency, scale and control within fiery entanglements Enviornment and Planning D: Society and Space, 34(6), 1080-1097

Eriksen, C. (2007). Why do they burn the 'bush'? Fire, rural livelihoods, and conservation in Zambia. The Geographical Journal, 173(3), 242-256.

Foucault, M. (1982). The subject and power. Critical inquiry, 8(4), 777-795.

Foucault, M. (2003). Society must be defended: lectures at the Collège de France. Trans. David Macey. New York: Picador.

Foucault, M. (2007). Security, Territory, Population. Palgrave Macmillan.

Garmany, J. (2010). Religion and governmentality: Understanding governance in urban Brazil. Geoforum, 41(6), 908-918. http://dx.doi.org/10.1016/i.geoforum.2010.06.005

Gill, A. M., \& Stephens, S. L. (2009). Scientific and social challenges for the management of fire-prone wildland-urban interfaces. Environmental Research Letters, 4 (3): 034014.

Glickman, D., \& Babbitt, B. (2001). Urban wildland interface communities within vicinity of Federal lands that are at high risk from wildfire. Federal Register, 66(3), 751- 777.

Grant, E. “Smokey.” Boys' Life, October 1957, p. 18, 105.

Hirsch, J. (1983). The Fordist security state and new social movements. Kapitalistate, $10 / 11,75 \mathrm{e} 87$.

Kosek, J. (2006). Understories: The political life of forests in northern New Mexico. Durham, N.C.: Duke University Press.

Kull, C. A. (2002). Madagascar aflame: landscape burning as peasant protest, resistance, or a resource management tool? Political Geography 21, 927-957. 
Kull, C. A. (2004). Isle of fire: the political ecology of landscape burning in Madagascar (Vol. 245). Chicago: University of Chicago Press.

Kull, C. A., \& Laris, P. (2009). "Fire ecology and fire politics in Mali and Madagascar." Tropical Fire Ecology. Springer Berlin Heidelberg, 171-226.

Latour, B. (2005). Reassembling the social: An introduction to actor-network-theory. Oxford: Oxford University Press.

Marlon, J. R., Bartlein, P. J., Gavin, D. G., Long, C. J., Anderson, R. S., Briles, C. E., ... \& Walsh, M. K. (2012). Long-term perspective on wildfires in the western USA. Proceedings of the National Academy of Sciences, 109(9), E535-E543. http://dx.doi.org/10.1073/pnas.1112839109

Mathews, A. S. (2003). Suppressing fire and memory: environmental degradation and political restoration in the Sierra Juárez of Oaxaca, 1887-2001. Environmental History, 77108.

Meehan, K., Shaw, I. G. R., \& Marston, S. A. (2013). Political Geographies of the Object. Political Geography, 33, 1-10. http://dx.doi.org/10.1016/j.polgeo.2012.11.002

Mitchell, T. (1999). State, economy, and the state effect. In G. Steinmetz (Ed.), State/culture: State-formation after the cultural turn (pp. 76-97). Ithaca: Cornell University Press.

Mitchell, T. (2011). Carbon democracy: Political power in the age of oil. Verso Books.

Nigh, R., \& Diemont, S. A. (2013). The Maya milpa: fire and the legacy of living soil. Frontiers in Ecology and the Environment, 11: e45-e54.

http://dx.doi.org/10.1890/120344

Olmsted, F.E. (1911). Fire and the Forest--The Theory of "Light Burning". Sierra Club Bulletin, 8(1), 43-47.

Olsen, C. S., Kline, J. D., Ager, A. A., Olsen, K. A., \& Short, K. C. (2017). Examining the influence of biophysical conditions on wildland-urban interface homeowners' wildfire risk mitigation activities in fire-prone landscapes. Ecology and Society, 22(1): 21. https://doi.org/10.5751/ES-09054-220121.

Painter, J. (2006). Prosaic geographies of stateness. Political Geography, 25(7), 752774. http://dx.doi.org/10.1016/j.polgeo.2006.07.004

Peloquin, C. (2013). "Locust Swarms and the Spatial Techno-Politics of the French Resistance During WWII" Geoforum, 49, 103-113. http://dx.doi.org/10.1016/j.geoforum.2013.06.005 
Philo, C. (2012). A 'new Foucault' with lively implications-or 'the crawfish advances sideways'. Transactions of the Institute of British Geographers, 37(4), 496-514. http://dx.doi.org/10.1111/j.1475-5661.2011.00484.x

Pyne, S. J. (1982). Fire in America: a cultural history of wildland and rural fire. Seattle: University of Washington Press.

Pyne, S. J. (1997). World fire: the culture of fire on earth. Seattle: University of Washington Press.

Pyne, S. J. (1998). Burning Bush: A Fire History of Australia. Seattle: University of Washington Press.

Pyne, S. J. (2001). Year of the fires: the story of the great fires of 1910. Viking Press.

Radeloff, V. C., Hammer, R. B., Stewart, S. I., Fried, J. S.; Holcomb, S. S., \& McKeefry, J. F. (2005). The wildland-urban interface in the United States. Ecological Applications, 15(3), 799-805.

Rose, N. (1999). Powers of Freedom: reframing political thought. Cambridge: Cambridge University Press.

Rose, G. (2001). Visual Methodologies. Thousand Oaks, California: Sage Publications.

Shaw, I. G. R., \& Meehan, K. (2013). “Force-Full: Power, Politics, and Object-Oriented Philosophy" Area, 45(2), 216-222. http://dx.doi.org/10.1111/area.12023

Simon, G. L. (2014). Vulnerability-in-Production: A Spatial History of Nature, Affluence, and Fire in Oakland, California. Annals of the Association of American Geographers, 104(6), 1199-1221.http://dx.doi.org/10.1080/00045608.2014.941736

Simon, G. L. (2016). Flame and Fortune in the American West: Urban Development, Environmental Change and the Great Oakland Hills Fire. Berkeley, California: University of California Press.

Stein, S. M., Menakis, J., Carr, M. A., Comas, S. J., Stewart, S. I., Cleveland, H., Bramwell, L., \& Radeloff, V. C. (2013). Wildfire, wildlands, and people: understanding and preparing for wildfire in the wildland-urban interface-a Forests on the Edge report. Gen. Tech. Rep. RMRS-GTR-299. Fort Collins, CO. U.S. Department of Agriculture, Forest Service, Rocky Mountain Research Station. 36 p.

Squire, R. (2015). Rock, water, air and fire: foregrounding the elements in the GibraltarSpain dispute. Environment and Planning D: Society and Space, 34(3), 545- 563. 
Sundberg, J. (2011). "Diabolic Caminos in the Desert and Cat Fights on the Rio: A Posthumanist Political Ecology of Boundary Enforcement in the United States-Mexico Borderlands" Annals of the Association of American Geographers, 101(2), 318-336. http://dx.doi.org/10.1080/00045608.2010.538323

Tàbara, D., Saurí, D., \& Cerdan, R. (2003). Forest fire risk management and public participation in changing socioenvironmental conditions: a case study in a Mediterranean region. Risk Analysis, 23(2), 249-260.

USDA Forest Service (2004). History of Smokey Bear. https://sdda.sd.gov/legacydocs/Forestry/educational-information/PDF/history-ofsmokeybear.pdf (Accessed 8 August 2016).

USDA Forest Service (2015). The Rising Cost of Wildfire Operations: Effects on the Forest Service's Non-Fire Work. August 4, 2015. http://www.fs.fed.us/aboutagency/budget-performance/cost-fire-operations. 17 pp. (Accessed 20 May 2016).

Westerling, A. L., Hidalgo, H. G., Cayan, D. R. \& Swetnam, T. W. (2006). Warming and earlier spring increase western US forest wildfire activity. Science, 313(5789), 940-943. 